\title{
Mathematics Teachers' Perceptions of the Introduction of ICT: The Relationship between Motivation and Use in the Teaching Function
}

\author{
Juan-Manuel Trujillo-Torres ${ }^{1}\left(\mathbb{D}\right.$, Hossein Hossein-Mohand 2,*(D), Melchor Gómez-García ${ }^{2}$ (D), \\ Hassan Hossein-Mohand ${ }^{2}$ (D) and María-Pilar Cáceres-Reche ${ }^{1}$ (D) \\ 1 Department of Didactics and School Organization, Faculty of Educational Sciences, \\ Universidad de Granada (UGR), 18071 Granada, Spain; jttorres@ugr.es (J.-M.T.-T.); \\ caceres@ugr.es (M.-P.C.-R.) \\ 2 Department of Pedagogy, Faculty of Teacher Training and Education, \\ Universidad Autónoma de Madrid (UAM), 28049 Madrid, Spain; melchor.gomez@uam.es (M.G.-G.); \\ hassan.hossein@estudiante.uam.es (H.H.-M.) \\ * Correspondence: hossein.hossein@estudiante.uam.es
}

Received: 30 September 2020; Accepted: 1 December 2020; Published: 3 December 2020

\begin{abstract}
Digital self-efficacy and the amount of perceived support from the school can improve teachers' motivation to increase the use of information and communication technology (ICT) in the classroom. Likewise, attitude, perception, gender, and experience of mathematics teachers are factors that influence their use of ICT. This study aimed to analyze the profiles of mathematics teachers, determine the existence of differences between them, and identify the sample size necessary to detect significant differences. A total of 73 high school teachers were included in this cross-sectional study. Teaching practice, ICT resources, ICT in the classroom, skills, and uses of ICT were assessed through a validated 19-item questionnaire. Statistical analysis revealed that the required sample to detect significant differences was 53 subjects. Further, $67.21 \%$ of the mathematics teachers surveyed in Melilla were younger than 40 years of age, and $62.30 \%$ had less than 6 years of teaching experience. In addition, 81.97 and $47.54 \%$ of mathematics teachers stated that they consider themselves to have sufficient ICT resources at home for their work and in the classroom, respectively. Through different clusters, mathematics teachers can be identified and classified according to their motivational and competence profiles in pedagogical and digital areas. In addition, young teachers with some teaching experience had positive perceptions of technology, as reflected by high scores in the motivation indicator for ICT.
\end{abstract}

Keywords: secondary teacher education; mathematics teachers; digital competence for teachers; professional development; teacher attitudes

\section{Introduction}

The statistical report of the Society of Information and Communication in non-university Spanish educational centers shows that during the 2018-2019 academic year, the percentage of classrooms with an internet connection was $96.8 \%$, and $94.3 \%$ had a wireless connection. In addition, the average number of teachers per computer was 1.9, and half of the available equipment corresponded to laptops and tablets. Moreover, $60.1 \%$ of classrooms had interactive digital systems (IDS), which include digital interactive whiteboards (IWB), multi-touch tables, interactive panels, and interactive TVs. The percentage of centers that intervened in educational experiences with technology was $37.5 \%$, of which $50.5 \%$ were secondary schools and $40.6 \%$ were vocational training facilities. The use of mobile phones in the classroom for educational purposes was $43.0 \%$ at the secondary level and $51.3 \%$ 
at the post-16 educational level [1]. The above data may suggest that information and communication technology (ICT) is important for educational purposes.

\subsection{The Teaching of Mathematics}

Chevallard (2005) defines didactics as the science of knowledge dissemination in any social group and studies elements of local or global praxeologies [2]. Each praxeology is composed of tasks, techniques, technologies, and a theory that justifies these technologies. In mathematics didactics, mathematical knowledge is acquired through learning and solving mathematical problems by means of the conceptual component of the schemes [3]. This knowledge is structured in differentiated constructs according to the theories of Brousseau and Chevallard, but the latter stresses the institutional conditioning factors in the didactics of mathematics [4]. During the resolution of mathematical problems, it is necessary to reflect on the most appropriate procedure and to analyze and distinguish the data, favoring the significant learning of the students [4]. For this purpose, teachers must be trained and must use tools and resources related to the didactics of mathematics [5].

Lagrange (2003) address the integration of technology in the didactics of mathematics and considers four key dimensions: student, teacher, tool, and mathematics [6]. From this study, seven central theoretical ideas that have influenced numerous subsequent studies are highlighted: the instrumental approach to the use of tools, instrumental genesis, pragmatic-epistemic duality, the technical-conceptual connection, work, the relationship between pencil and pencil versus digitally instrumented technique, the institutional aspect, and theory networking [7].

In the didactics of mathematics, the use of appropriate technologies facilitates the understanding of procedures and the distinction of the most relevant data [8]. In addition, mathematical developments in dynamic technologies promote new mathematical practices in different contexts such as dynamic geometry, statistics, and robotics [9]. On the other hand, Moreno et al. (2018) identify three ways to integrate technological resources: 1 . paying more attention to the results than to the solution process and giving less importance to students' mathematical activity; 2 . organizing a lesson plan taking into account mathematical activity and taking advantage of technological resources in problem solving; 3. using only dynamic representations of problems to show mathematical relationships [10].

In this sense, the most effective teachers establish pedagogical relations between content and technology through instrumental genesis [11]. The process in which an artefact becomes an instrument is called instrumental genesis [6]. It can also be defined as the shaping of thought that describes the process of how an artefact becomes an instrument and shows the procedures in which technologies support the learning of mathematics [12]. The instrumental genesis for teaching mathematics through technology is a complex process that requires time [13].

In general, studies that analyze technologies in the didactics of mathematics have focused on: the digital tools used, the pedagogical bases and objectives of the activities, and the levels of integration of technology in mathematics teaching [14]. However, since the beginning, there has been a disparity with respect to the theoretical frameworks used in the design of technological tools and the realization of research with these tools [6], making it difficult to generalize conclusions. In this sense, the figure of the teacher is essential for the adequate integration of ICT in the teaching of mathematics [15].

It has been shown that the incorporation of ICT into teaching practices is conditioned by various factors, such as the characteristics and quantity of available technological resources [16]. In spite of the fact that technology endowments are important in secondary schools [1] and at higher education levels [17], teachers usually have a low or medium level of digital competence [18]. However, perceptions, attitudes, and methodological uses of ICT are factors to be taken into account [19], and also, uses differentiated by gender [20], age, and teaching experience have been observed [17].

\subsection{Attitudes towards ICT}

The perceptions that teachers have towards ICT is one of the factors that influence its use [19]. However, attitude is another conditioning factor. Attitude can be defined as a guide to teacher behavior, 
consistent with their perceptions [21]. A recent study classified attitudes into three dimensions: active, cognitive, and behavioral [22]. The active dimension involves the feelings and emotions that stimulate decision making. Regarding the cognitive dimension, it is maintained by the beliefs and values associated with the experience of each teacher. Finally, the behavioral dimension focuses on the behaviors and intentions of the teacher in the face of a certain circumstance in which they must act [23]. Conditioning factors can be classified into the following categories: knowledge, attitude, and skills [24].

However, the support perceived by the teacher drives the incorporation of pedagogical ICT resources [25]. Furthermore, digital competence and motivation are correlated with their integration in the classroom [26]. Self-determination is one of the most influential motivational models for improving the perception of technology [27]. In this sense, digital self-efficacy and the support perceived by an educational center can improve the motivation of teachers and their commitment to design innovative training programs [27]. Training is another factor that affects the perception of technology and the incorporation of ICT into teaching practices [28].

\subsection{Use of ICT}

In recent years, education has undergone a substantial transformation as a consequence of the effect of ICT $[29,30]$. Methodological strategies have been developed thanks to technology, strengthening active methodologies. These include the flipped classroom [31-33], game-based learning [34-36], and project- or problem-based learning [37,38]. Different studies have analyzed the use of ICT for teaching mathematics in primary schools $[35,39,40]$, secondary schools $[33,41]$, and for higher level studies [38]. The importance of their integration has even been shown in classrooms with students with disabilities [42].

The available literature postulates that the proper use of ICT benefits collaborative work [37] and student learning $[43,44]$ and has an impact on their academic performance $[17,45]$. Nevertheless, teachers continue to use traditional methodologies with textbooks and boards [30]. They make limited use of technology, using it mainly for searching on the Internet for information or for administrative purposes [46]. Regarding IWBs, they mainly use them as a tool for lesson delivery in the classroom [47] and do not take their pedagogical potential into account $[18,48]$. This teacher-centered approach to teaching does not encourage participatory and collaborative work by students [49], nor does it take advantage of the innovative functions of IWBs [50]. Similarly, teachers do not incorporate current educational technologies into their teaching practices in order to improve them [19].

ICT reinforces cognitive and creative abilities as well as communicative skills, but technology alone does not add value [51]. The highest performance is observed if the teacher brings together technological, pedagogical, and integration efficiencies in its three domains [52]. In this regard, the success of ICT in education depends a lot on the digital autonomy acquired by teachers because of their digital competence, professional development, and the training provided to teachers [53].

However, it has been observed that technology has negative effects on the teaching-learning process. The teaching process is affected, among other factors, by the negative effect of technostress (stress associated with technology) on teachers [54]. Technostressors associated with insecurity, uncertainty, invasion, complexity, and overload significantly affect teacher burnout and professional performance [55]. These effects have a greater impact on older teachers [54], but no gender differences have been observed [55]. Self-efficacy significantly reduces the effects of technostressors [56]. As for students, no negative effects of technology caused by technostress on students when using mobile devices have been shown [57]. On the other hand, previous findings revealed a negative impact of ICT methods that require active participation by students [58]. This negative effect is significantly reduced if teachers have a high level of digital competence [58]. 


\subsection{Age, Gender, and Teaching Experience}

Preservice teachers show more favorable attitudes towards the use of ICT in the classroom [21]. However, they the lack digital skills that include lifelong learning, the optimal use of ICT, and their implementation of active methodologies [59]. In general, they show skills acquired during their time as students, such as browsing, interacting, sharing information, and storing and retrieving data and digital content [60]. In this sense, the teaching experience is negatively correlated with digital competence and with its integration and pedagogical use in the classroom [26,61]. Furthermore, it has been postulated that age and teaching experience do not influence attitudes towards technology, although in higher education, the use of technology is more widely accepted by university lecturers [23].

Regarding gender, a recent report by the International Association for the Evaluation of Educational Achievement (IEA) pointed out a significant difference in favor of male teachers regarding the use of ICT in almost all countries of study [62]. Gender differences are attributed to a low level of confidence in the use of technology by women [63]. It has been concluded that female teachers make less use of IWBs than male teachers [20]. In [47], it was stated that male teachers have a greater ability to solve technical problems, encouraging the use of ICT in the classroom. Furthermore, male teachers show lower levels of anxiety and greater confidence than female teachers [64].

However, a recent study on teachers' perceptions and uses of ICT showed that gender differences are not significant in terms of the pedagogical use of ICT [65]. Nevertheless, differences of little significance have been observed in favor of female teachers regarding ICT teaching [63]. Therefore, it is necessary to structure training programs that promote the participation of women to eliminate the digital gender gap [66].

\subsection{Justification}

The early education and training drop-out rate measures the proportion of 18-24-year-old youngsters who dropped out of high school and did not continue their training. The data source is provided by Eurostat, from the Labour Force Survey (LFS), based on annual averages of quarterly data. In 2018, the early drop-out rate in the European Union was 10.6\%; in Spain, it was $17.9 \%$. The highest rate of early school drop-out is in the Autonomous City of Melilla 29.5\%. This is 11.6 percentage points above the national average. These results are not occasional; in 2010, it was 35.4\%, and in 2002, it was 28.0\%. The city also has the highest ratios per classroom in Spain and Europe [67].

Carried out focusing on Melilla's students and mathematics teachers. It is considered appropriate to analyze the mathematics teachers as one of the factors that have a significant impact on the students and their academic performance [39]. In the present study, the relationship between mathematics teachers and ICTs has deepened, by analyzing the possible influence of mathematics teachers' perceptions of ICTs, and their motivation for their pedagogical use in the classroom. For this purpose, some items of the dimensions-B. Mathematics and Teaching Practice and C. ICT in the Teacher's Environment-are analyzed.

Taking into consideration the mentioned background, the present study pursues the following objectives: (1) to determine the sample size necessary to detect significant differences; (2) to analyze mathematics teachers' perceptions and motivations regarding ICT; (3) to identify the clusters that allow for teachers to be grouped regarding their perceptions. In order to achieve the these objectives, the following research questions were posed: PI1: Does the sample obtained allow detecting significant differences?; PI2: How does ICT motivate the mathematics teachers to teach?; PI3: Do gender, age, and teaching experience influence the perceptions and motivations towards ICT?; PI4: How are the items of the indicators C.2 "ICT and Teaching" and C.4 "Motivation" related?; PI5: Is it possible to identify similar profiles among mathematics teachers? 


\section{Materials and Methods}

This descriptive, quantitative, observational study [68] aimed to evaluate the effects of perceptions and motivation on ICT use by mathematics teachers in Melilla. The selection criteria for the study population were (1) residents of the AC of Melilla, (2) high school teachers, and (3) mathematics teachers. The sample obtained included 73 teachers ( $34.25 \%$ women and $65.75 \%$ men). The final sample collected covered all educational centers in Melilla and included 61 teachers, which accounted for $83.56 \%$ of the population, of which $34.42 \%$ were women. The sample differentiation by age was as follows: less than 30 years- $8.20 \%$; between 31 and 40 years-26.23\%; between 41 and 50 years- $40.98 \%$; between 51 and 60 years- $13.11 \%$; over 61 years- $11.48 \%$.

The quantitative instrument was designed ad hoc with the following phases: (i) literature review; (ii) establishment of the dimensions of the questionnaire; (iii) formulation of items; (iv) validity of content through expert judgment; (v) validity of construction; (vi) reliability analysis [69]. The instrument was validated by experts to determine its reliability and validity values. The internal consistency of the obtained data matrix was also verified by checking the consistency of the items. The results are optimal since the Tucker Lewis index of factoring reliability was 0.965 .

The full questionnaire totaled 107 questions and covered the dimensions of B. Mathematics and Teaching Practice; C. ICT in the Teaching Environment; D. Uses, Resources, and Mastery of ICT; E. ICT and Society. The majority of the questionnaire was configured ad hoc with closed 4-level Likert graduated items (1, none; 2 , a little; 3 , enough; 4 , a lot). The 19 items analyzed in this study were related to the dimensions of the active methodologies applied by mathematics teachers, Teaching Practice, ICT resources, ICT in the classroom, ICT mastery, and ICT consumption on working days (Monday to Thursday). The questionnaires were administered to teachers during the third quarter of 2018-2019 in an online format through "Google Forms" to ensure reliable data collection and avoid bias.

Statistical power was calculated using the function "pwr.t.test", with the following parameters: $\mathrm{D}=0.77$; sig.level $=0.05$; power $=0.99$; alternative $=$ greater. We determined that 53 subjects were needed to detect significant differences.

\section{Procedure}

In the execution of inferential statistics, the outliers were corrected with the median of the corresponding column. Subsequently, once the variables under study had been converted to numerical variables, the Yeo-Johnson algorithm was applied to improve the normality of the data [70,71]. The variance inflation factor (vif) was less than 10 in all cases. Thus, it was not necessary to eliminate any of the variables of the study. The steps followed prior to the deployment of the cluster analysis were as follows: (1) centering and scaling of regressors other than binary ones; (2) calculation of the adjacency matrix; (3) pruning of the adjacency matrix in such a way that the diagonal had a value of 0 ; (4) elimination of duplicate relationships. For this, R Studio software was used.

The associations of each item with their indicators and corresponding dimensions, as well as the associated codes, are detailed in Table 1. 
Table 1. Relationship between items, indicators, dimensions, and codes used in the questionnaire.

\begin{tabular}{|c|c|c|}
\hline \multicolumn{3}{|r|}{ Dimension A. Teacher Data/Indicator A.1 General Data } \\
\hline ID & Code & Items \\
\hline A.11 & QUT & How old are you? \\
\hline A.12 & GEN & Gender \\
\hline A.16 & AED & How many years of teaching experience do you have? \\
\hline \multicolumn{3}{|c|}{ Dimension B. Mathematics and Teaching Training/Indicator B.2 Teaching Practice } \\
\hline B.21 & ADA & I adapt my teaching to what the student understands at all times \\
\hline B.22 & AEC & I am conscious of my students' most common successes and errors \\
\hline B.24 & EAA & I evaluate student learning in different ways \\
\hline \multicolumn{3}{|c|}{ Dimension C. ICT in the Teachers' Environment/Indicator C.1 ICT Training } \\
\hline C.13 & FTD & I consider ICT training to be essential for teaching practices \\
\hline C.15 & DIU & I consider proficiency in English to be necessary for the proper use of ICT \\
\hline \multicolumn{3}{|r|}{ Indicator C.2 ICT and Teaching } \\
\hline C.23 & TMA & I select technologies that improve student learning in a lesson \\
\hline C. 24 & LTD & $\begin{array}{c}\text { I can teach lessons that adequately combine mathematics, technology, and } \\
\text { teaching approaches }\end{array}$ \\
\hline C. 25 & TMC & $\begin{array}{l}\text { I select technologies to use in the classroom that improve the content I teach, } \\
\text { the way I teach it, and what the students learn }\end{array}$ \\
\hline C.26 & MDE & $\begin{array}{l}\text { Within the classroom teaching materials, I use strategies that combine } \\
\text { content, technologies, and teaching approaches from which I have learned }\end{array}$ \\
\hline C.27 & CCT & I take the use of ICT into account in the marking criteria \\
\hline C.28 & UHD & $\begin{array}{c}\text { I use digital tools to carry out the assessment, tutoring, and/or monitoring of } \\
\text { the students }\end{array}$ \\
\hline \multicolumn{3}{|r|}{ Indicator C.3 ICT Resources } \\
\hline D.32 & DAT & $\begin{array}{l}\text { I use the tools or software on the interactive digital board to teach } \\
\text { mathematics classes }\end{array}$ \\
\hline D.33 & DRT & $\begin{array}{l}\text { I use virtual learning environments (Moodle, Webct... ) to teach } \\
\text { mathematics classes }\end{array}$ \\
\hline \multicolumn{3}{|r|}{ Indicator C.4 Motivation } \\
\hline C. 41 & MTD & $\begin{array}{c}\text { I am motivated by the use of ICT in the classroom because it makes my } \\
\text { teaching easier }\end{array}$ \\
\hline C. 42 & MTT & $\begin{array}{c}\text { The use of ICT in the classroom motivates me because it simplifies my work } \\
\text { (content preparation, exams, ... }\end{array}$ \\
\hline C. 44 & MTA & $\begin{array}{l}\text { I am motivated by the use of ICT in the classroom because it improves the } \\
\text { academic results of the student body }\end{array}$ \\
\hline
\end{tabular}

First of all, it is necessary to address the first objective of this study. For this purpose, the Mann-Whitney U test-more specifically the Wilcoxon rank sum test with continuity correction-was used, since there were two independent groups (men and women) that acted as the ordinal variable regressors or predictors. In order to determine the necessary sample size in the case of significant gender differences, variable DIU was used (I consider English proficiency to be necessary for the adequate use of ICT). The reason for this was that it is necessary to use two variables for this type of analysis, and the exposed results were carried out on the variable with a lower $p$-value, that is, DIU ( $\mathrm{n}=53.88963 ; \mathrm{d}=0.77$; sig.level $=0.05$; power $=0.99$; alternative $=$ greater $)$. The Mann-Whitney $U$ test was used because the samples were independent and because the given variables were ordinal.

\section{Results}

The results of the Mann-Whitney $U$ test showed gender differences only for variable DIU ("I consider English proficiency to be necessary for the adequate use of ICT") (W = 259.5, $p$-value $=0.008222$ ) and MTT ("The use of ICT in the classroom motivates me because it simplifies my work (content preparation, exams, $\ldots$ " $)(\mathrm{W}=307, p$-value $=0.04564)$. Responding to the research 
question PI1: Does the sample obtained allow detecting significant differences? The findings revealed that to detect significant differences, 53 subjects needed to be required, a sample size that is smaller than that of the study sample. The outcome was $99 \%$ with a confidence level of $95 \%$, which indicates that if we were to repeat the study, relevance would be obtained $99 \%$ of the time. These are ideal results considering that, generally, the appropriate outcome level is $80 \%$.

However, in the analysis of the profiles of mathematics teachers, all variables included in the study were determined based on the scales used in the questionnaire. The descriptive results are shown in Table 2.

Table 2. Descriptive results shown by level of the independent variable.

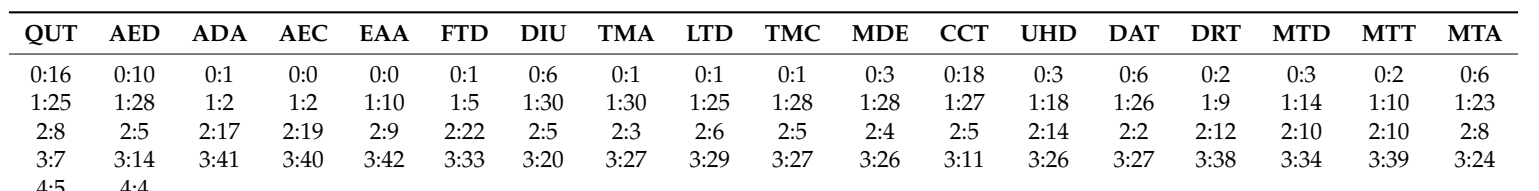

$4: 5 \quad 4: 4$

Note: The coding of the scores were as follows: for QUT (0. less than 30 years; 1 . between 31 and 40 years; 2. between 41 and 50 years; 3. between 51 and 60 years; 4 . more than 61 years), for AED (0. less than 1 year; 1. between 2 and 5 years; 2 . between 6 and 10 years; 3 . between 11 and 20 years; 4 . more than 21 years), and for the rest of the items ( 0 . not at all; 1 . little; 2 . rather a lot; 3 . a lot).

In Table 2, it can be observed that $67.21 \%$ of the mathematics teachers surveyed in Melilla were under 40 years of age, and $62.30 \%$ had less than 6 years of teaching experience. In addition, when the items related to the ICT and teaching indicator were analyzed, it was observed that an average of $50 \%$ of the teaching body responded "little or none" to TMA (I select technologies that improve student learning in a lesson), TMC (I select technologies to use in the classroom that improve the content that I teach, the way of teaching it, and what the students learn), LTD (I can teach lessons that adequately combine mathematics, technologies, and teaching approaches), and MDE (Within the classroom teaching materials, I use strategies that combine content, technologies and teaching approaches from which I have learned), while for CCT (I take the use of ICT into account in the marking criteria), the response was $73.77 \%$, and for UHD (I use digital tools to carry out the evaluation, tutoring and/or monitoring of the students), it was $34.43 \%$.

For the motivation indicator, $19.67 \%$ of teachers responded "a little or not at all" for MTT (I am motivated by the use of ICT in the classroom because it simplifies my work (content preparation, exams), $27.87 \%$ responded this way for MTD (I am motivated by the use of ICT in the classroom because it facilitates my teaching work), and $47.54 \%$ for MTA (I am motivated by the use of ICT in the classroom because it improves the academic results of the student body.) In relation to the variable FTD (I consider ICT training to be essential for teaching practices), only 9.83\% responded "little or not at all".

Regarding ICT resources, $81.97 \%$ of mathematics teachers responded "rather a lot or a lot" for DRT (I consider that I have sufficient ICT resources at home for my daily work), and $47.54 \%$ gave this response for DAT (I consider that I have sufficient ICT resources in my classroom for my daily work). From the point of view of teaching practice, $95.08 \%$ respond highly for ADA (I adapt my teaching to what the student understands at all times), which was in line with the $96.72 \%$ who gave this response for AEC (I am conscious of my students' most common successes and errors) and the $83.61 \%$ who gave this response for EAA (I evaluate student learning in different ways).

Statistical analyses (Figure 1) revealed significant positive correlations between TMA (I select technologies that improve student learning in a lesson) TMC (I select technologies to use in the classroom that improve the content I teach, the way of teaching it, and what the students learn), MDE (Within the classroom teaching materials, I use strategies that combine content, technologies, and teaching approaches from which I have learned), and LTD (I can teach lessons that adequately combine mathematics, technologies, and teaching approaches). In addition, other less significant associations were observed between TMC and MDE and between MDE and LTD. In summary, there is 
a significant correlation between all of the items of the indicator C.2 ICT and Teaching. On the other hand, the low correlation with UHD shows that the evaluation and monitoring of students with digital tools is not associated with teaching.

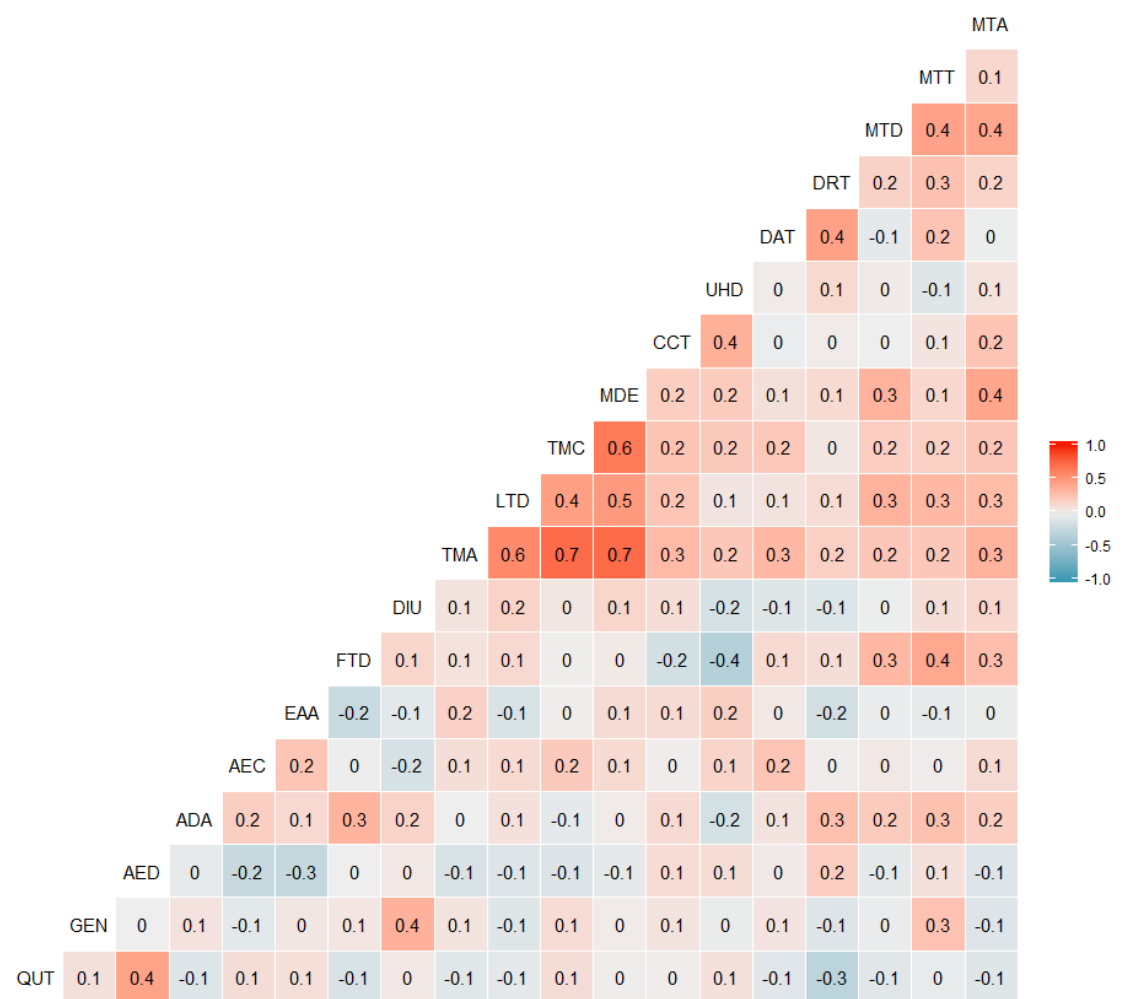

Figure 1. Correlations between the variables of the study.

However, very weak correlations were found between the variables of the study. It is worth highlighting the correlations between FTD (I consider ICT training to be essential for teaching practices) with UHD (I use digital tools to carry out the assessment, tutoring, and/or monitoring of students) and between AED (teaching experience) and EAA (I evaluate student learning in different ways). These results can be interpreted as the evaluation and monitoring of students with digital tools is associated with the training in technologies of indicator C.1 ICT Training and that the teaching experience correlates with indicator B.2 Teaching Practice. In both cases, the correlations are weak.

In response to the research question PI4: How do the items of the indicators C.2 ICT and Teaching and C.4 Motivation relate? When the indicator C.2 ICT and Teaching was analyzed, weak correlations are observed with the items MTA (I am motivated by the use of ICT in the classroom because it improves the academic results of the student body), MTT (I am motivated by the use of ICT in the classroom because it simplifies my work (content preparation, exams, ... )), and MTD (I am motivated by the use of ICT in the classroom because it makes my teaching easier) for the C.4 Motivation indicator. That is, the weak correlations between the indicators C.2 ICT and Teaching and C.4 Motivation show that motivation does not explain the use of technologies by the mathematics teacher.

Regarding the research question PI3: Does gender, age, and teaching experience influence perceptions and motivations towards ICTs? Note that there were no significant correlations between the C.2 ICT and Teaching indicator and gender, age, or teaching experience. It also did not correlate with FTD (I consider ICT training to be essential for teaching practices) or DAT (I consider that I have sufficient ICT resources in my classroom for my daily work). Similarly, no relationships were observed between the C.4 Motivation indicator and gender, age, or teaching experience. On the other hand, no significant correlations are observed between the indicator C.3 ICT Resources with the rest of the indicators in the study. This result can be interpreted as having ICT resources does not explain the 
motivation of the mathematics teachers in Melilla towards technology. It is neither associated with teaching practice or training. Similarly, motivation is not associated in a significant way with ICT training. This is the answer to the research question PI2: How do ICTs motivate mathematics teachers to teach?

The previous results do not allow us to differentiate the teachers' profile based on gender, age, and teaching experience. Then, PI5: Is it possible to identify similar profiles among mathematics teachers? In order to identify teacher communities, the following figure of networks unsupervised (Figure 2) is proposed. Due to the sample obtained in the present study, neurons have not been used, but networks' unsupervised analysis (Edges) have, using a Threshold. As a result of lost data, data were initially imputed using the random forest algorithm. Then, these data were focused and scaled using the $\mathrm{R}$ Studio "recipe" function and a training group with $85 \%$ of the data selected. This percentage was used due to the sample size. It is noted that the algorithm used was networks unsupervised analysis due to the multitude of dependent variables. That is, there was not a single dependent variable in the input. This situation was considered for Figures 1 and 2. The unsupervised analysis is used because we do not know a priori the number of groups that are going to be formed. Secondly, the adjacency matrix was calculated, and it was pruned in a way that there were 0 diagonal elements and an edge limit of $99.6 \%$ was set. The figure acquired was obtained from "prep corr matrix for tbl graph". The H2O algorithm was used to validate this process.

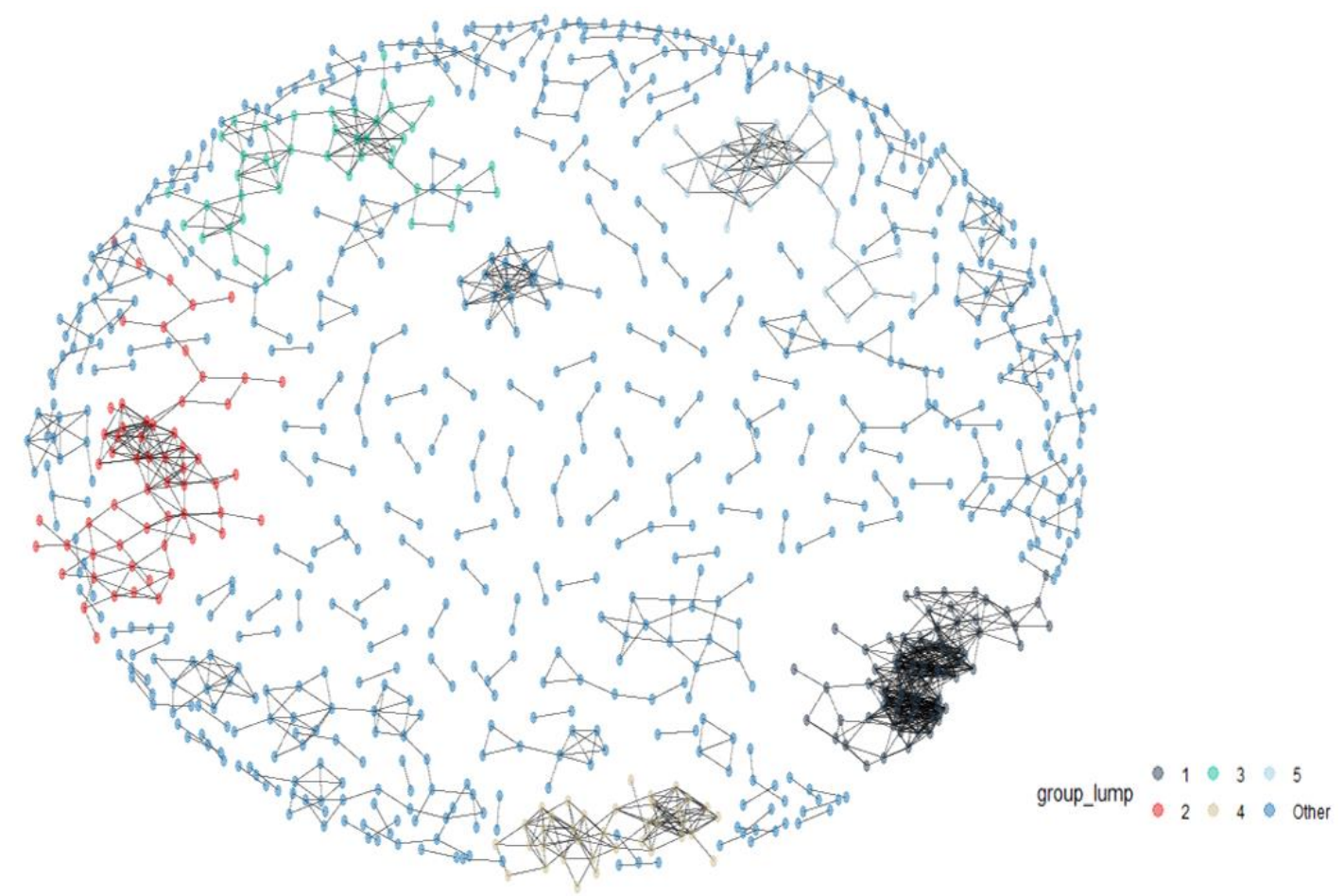

Figure 2. Math teaching community network. Networks' unsupervised analysis for the sample of the study.

The results of the clustering analysis through networks unsupervised analysis allowed for the identification of five communities of mathematics teachers in the Autonomous City of Melilla, although, communities 1 and 2 were the ones that presented the highest level of consistency. Communities 1, 2, and 4 were the most significant. In other words, teachers are well grouped into these three clusters.

This figure was displayed for two purposes: to identify the teachers' communities and their compaction, as seen in the cluster concentration. Then, to distinguish several clusters, Figure 2 was implemented to determine which subjects belonged to each group. In order to analyze the most 
prominent clusters in the previous figure, a partitioning around medoids process was carried out (see Figure 3). The reason for this was to determine which participants formed each group.

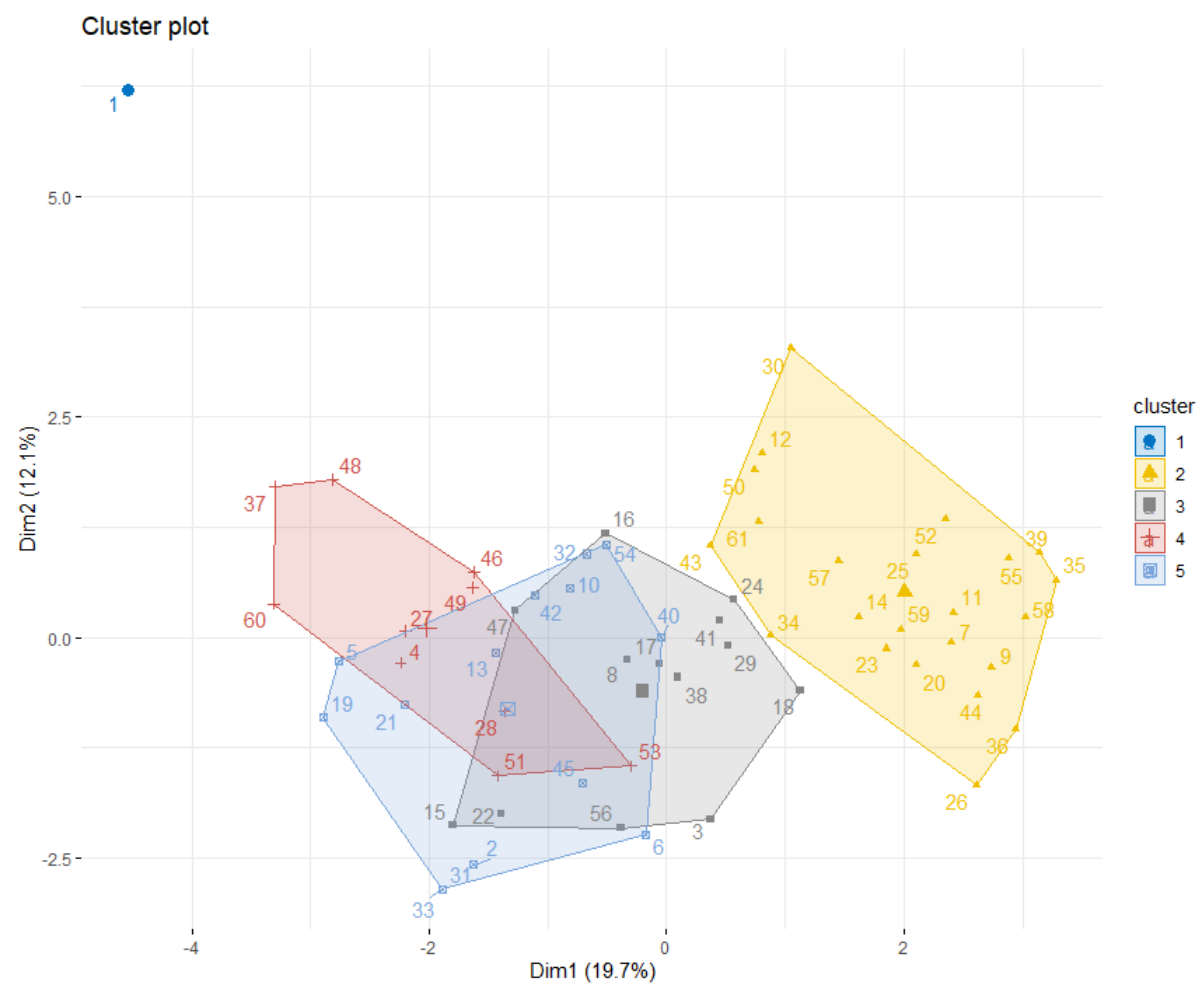

Figure 3. K-Means. Partitioning around medoids.

In order to develop the previous networks unsupervised analysis and to see it accurately, Figure 3 (K-Means) was developed. This shows the complete concrete cases identifying each individual. The yellow cluster corresponds to the black cluster of the networks unsupervised analysis, and the gray cluster corresponds to the red cluster, with both of them being the most compact clusters. Cluster 4 in Figure 2 correspond to cluster 1 in Figure 3. It was observed that the clustering was not consistent and identifying subjects that belonged to three clusters simultaneously would tend to offer ambiguous conclusions.

In Figure 3, the profiles of the mathematics teachers can be seen, that is, the individuals who scored similarly in the study were identified. A more compact cluster indicates a teaching community that is easier to group than another. It is interesting to examine the teacher communities to compare these results with those displayed in the previous networks unsupervised figure. One of the new features of this study was determining the IDs of the participants who took part. To this end, these findings will be critical for the development of effective individualized and personalized action plans that affect the professional competencies shown by teachers. However, to know the characteristics of each group requires a case study that analyzes the specific characteristics of the members of each cluster.

\section{Discussion}

In the present study, $81.97 \%$ of mathematics teachers surveyed claimed to have sufficient ICT resources at home, and $47.54 \%$ claimed to have sufficient resources in the classroom for their daily work. These statements are in line with data from the Ministry of Education and Vocational Training Statistics on ICT resources in classrooms, which revealed that more than $90 \%$ of classrooms have a wireless internet connection. In addition, $60.1 \%$ of classrooms have SDI, and the average ratio is 1.9 teachers to a computer [1]. A report on ICT equipment and its use in Spanish homes indicated that $90.7 \%$ have Internet access and $80.9 \%$ have a computer at home [72]. 
However, in relation to the C.2 ICT and Teaching indicator, 50\% of teachers responded "little or not at all" for the indicators TMA, TMC, LTD, and MDE, while $26.23 \%$ and $65.67 \%$ responded "a lot or rather a lot" to the indicators CCT and UHD, respectively. These data suggest that teachers' perceptions of technology and teaching experience influence the use of ICT when teaching mathematics in the classroom. The literature postulates that the figure of the teacher is fundamental for the adequate integration of ICT in the teaching of mathematics [15]. Likewise, the results for the item CCT revealed that a large percentage of teachers do not take ICT into consideration in their mathematics marking criteria. Melilla's mathematics teachers can be considered as belonging to group 3 in terms of integrating technology in the classroom. That is, they only use dynamic representations of problems to show mathematical relations [10]. Instead, teachers use digital tools for student assessment and monitoring. In this sense, the literature maintains that the teaching body has sufficient pedagogical content knowledge to evaluate student learning from a broad perspective [73]. However, it is necessary to reflect deeply on teachers' marking criteria and the need for adequate training in this regard [74].

Regarding teaching practices, $95.08 \%$ of teachers surveyed affirmed that they adapt their teaching to students, $96.72 \%$ stated that they are aware of the most common types of successes and errors, and $83.61 \%$ stated that they evaluate student learning in different ways. Among the mathematics teachers surveyed in this study in Melilla, $73.77 \%$ were over 30 years old and $83.61 \%$ had more than 1 year of teaching experience. It has been postulated that teaching experience is associated with the use of effective teaching methodologies, albeit with a traditional approach, and there is a certain reluctance towards the incorporation of technology into teaching practices [26,59]. In relation to this, previous studies have shown generally low values in preservice teachers, with little experience in using methodological strategies to teach mathematics and use marking criteria appropriately [75]. The convenience of using other instruments to improve teaching functions has been emphasized [76].

However, the high scores obtained for the motivation indicator by mathematics teachers is worth noting. A total of $80.33 \%$ of the teaching staff affirmed that they feel very motivated by ICT because it facilitates their work, $72.13 \%$ stated that it facilitates their teaching practices, and $52.46 \%$ stated that it improves the academic results of the student body. In this sense, the most effective teachers establish pedagogical connections between contents and technologies through instrumental genesis [11]. In addition, $90.17 \%$ stated that they consider ICT training to be essential for teaching practices. Similarly, [27] affirmed that teachers are motivated if they receive support from the Educational Centre, considered as institutional determinants in the didactics of mathematics [2]. In contrast, a lack of support, especially from the management team, combined with low motivation on the part of the students, is associated with the burnout of teaching staff and abandonment of the teaching role [25]. Nevertheless, in line with the results for the indicators MTA and FCD used in this study, various authors have proposed that the use of ICT improves student learning and performance $[23,43]$.

However, positive but weak correlations were observed between the ICT and teaching indicator and the motivation indicator. In other words, motivation does not explain the use of technology by the mathematics teacher. These results could be explained by taking the profiles of the mathematics teachers surveyed into account. We found that $83.61 \%$ of those surveyed had more than one year of experience and $67.21 \%$ were under 40 years of age. Conversely, the literature maintains that the age of mathematics teachers is negatively correlated with their use of ICT. In general, experienced teachers do not incorporate ICT into their lessons to improve their educational practice [19]. A previous study considered training to be the most important factor in determining the integration of ICT into the classroom due to its impact on teachers' perceptions of technology and the improvement of digital competence [77].

Other less significant associations were observed in the present study between TMC and MDE and between MDE and LTD. The results of recent studies suggest that the use of ICT by teachers is conditioned by the availability of technological resources and their quality [16]. However, other findings show that, despite the availability of technological resources, teachers continue to use traditional 
methodologies [30] and do not take advantage of the potential of IWBs because they do not clearly see the benefits of their use $[47,50]$ or of their pedagogical potential for teaching [48]. In the present study, a significant correlation is observed between virtually all of the items of the indicator C.2 ICT and Teaching. However, the low correlation between FTD and UHD shows that the evaluation and monitoring of students with digital tools is associated more with ICT training than with teaching, with the correlation being weak.

On the other hand, the analysis between the indicators of the present study does not show significant correlations between the indicator C.3 ICT Resources with the rest of the indicators of the study. This result may explain that the fact of having ICT resources does not motivate Melilla's mathematics teachers to use technology. It is neither associated with teaching practice or training. Instead, there is a relationship between motivation and training in ICT. The available evidence postulates that one of the factors that influences the use of ICT is its perception by teachers [23] and whether they have a positive attitude towards its use in the classroom [21,28]. In addition, [21] argued that new teachers use ICT more frequently than teachers with more experience. In the present study, the positive responses of mathematics teachers to the motivation and perceptions of training indicators suggested that these factors are more relevant than teaching experience. For this reason, strong correlations appeared between the selection of technologies as a pedagogical tool due to their impact on learning, the transmission of content, and the influence on the teaching of mathematics. In line with the above, [28] postulated that a positive attitude towards technology in general facilitates learning and encourages the use of ICT by the teacher inside and outside of the classroom.

In the present study, no significant correlations were found between the ICT and teaching indicator and gender, age, or teaching experience. The above variables were not correlated with ICT training for teaching practices. However, recent studies showed a positive correlation between having less teaching experience and the use of technological resources in the classroom [21]. Similarly, a negative correlation was observed between teaching experience and digital competence and use of ICT in the classroom [26]. Age has been shown to be an influential variable when predicting ICT use, but teaching experience did not show a significant correlation with it [23]. In addition, several authors observed significant positive correlations between age and technostress present in teachers [55,78].

Regarding gender, men have been shown to have greater use of IWBs [20], greater efficacy towards solving technical problems, and greater confidence in the use of ICT [64]. For this reason, specific teacher training programs that reduce this inequality are recommended [66]. In contrast, a recent study on teachers' perceptions and uses of technologies, covering 13 countries, showed that gender differences are not significant in terms of the pedagogical use of ICT [63]. The findings of several studies showed no gender differences associated with technostress [54,55]. In the present study, correlations were not observed between the motivation indicator and gender, age, or teaching experience. However, it has been determined that motivation is negatively correlated with teaching experience, which, in turn, conditions the integration of ICT into teaching methodologies [26].

In relation to the results shown in Figures 2 and 3 of neural networks, related profiles of mathematics teachers were identified in these clusters. The use of such clusters would allow the initiation of customized vocational training programs that are appropriate to the teachers' competency profiles. The findings postulate that by classifying teachers based on their digital competence, effective learning environments that encourage the use of ICT in teaching practice can be designed and pedagogical strategies can be expanded [79]. In addition, having effective training actions would reduce the stress on teachers by strengthening the actions of specific technostress inhibitors such as digital literacy, technical support, and the promotion of active participation $[54,55,80]$. Support programs include training in the didactics of mathematics and in the use of its tools and resources [5], training to improve the digital competence of mathematics teachers [77], and to encourage women's participation, thereby reducing the gender gap associated with technology [66]. 


\section{Conclusions}

This study has demonstrated the possibility of defining different clusters of mathematics teachers according to motivational and competence profiles in the pedagogical and digital areas. This information is essential for the design of personalized training and teaching support programs appropriate to the needs of teachers and to reduce the effects of technostress in teachers.

Referring to the general profile of mathematics teachers in Melilla, young teachers with some teaching experience were found to have a positive perception of technologies with high scores for the indicator regarding motivation toward ICT, because it facilitates tasks, benefits the teaching function, and improves the students' performance. In addition, teachers stated that they consider ICT training to be essential for the teaching function. No correlation with teaching experience was found. In contrast, the methodological approach of mathematics teachers is generally traditional with little use of ICT to teach mathematics. In addition, teachers stated that they did not contemplate the use of ICT by their students in their qualification criteria. In this study, no significant gender differences were found.

One of the main limitations of the study regards the items analyzed and the nature of the questionnaire. However, this point was also a strength as it allowed an interdimensional analysis of the teaching staff. Another limitation of the study is the lack of information provided by network analysis on the characteristics of the subjects. The size of the study could be considered to be another limitation that could have affected our ability to generalize the results and the robustness of the conclusions obtained, but the statistical power indicated that the sample is representative. Nevertheless, due to the sample size, there are certain limitations to the generalization of the second conclusion. On the other hand, the context and approach of the study, the statistical analyses used, and the usefulness of the results obtained are strengths.

Finally, the results encourage further study on professional training and an in-depth analysis of teaching and digital competence from a different perspective. A proposal for future studies is to contrast the method used in the present study, with a LIME analysis, to obtain more complete information on the profiles of mathematics teachers. The most direct practical application is the design of effective personalized training programs focused on high-content teachers that reduce technostress among this group whose role is fundamental in teaching.

Author Contributions: Conceptualization, H.H.-M. (Hossein Hossein-Mohand) and J.-M.T.-T.; methodology, H.H.-M. (Hossein Hossein-Mohand) and J.-M.T.-T.; software, H.H.-M. (Hassan Hossein-Mohand); validation, H.H.-M. (Hassan Hossein-Mohand), M.G.-G., M.-P.C.-R., and J.-M.T.-T.; formal analysis, M.G.-G. investigation, H.H.-M. (Hossein Hossein-Mohand); resources, H.H.-M. (Hossein Hossein-Mohand); data curation, H.H.-M. (Hossein Hossein-Mohand); writing-original draft preparation, H.H.-M. (Hossein Hossein-Mohand); writing-review and editing, H.H.-M. (Hossein Hossein-Mohand) and J.-M.T.-T.; visualization, M.G.-G.; supervision, M.G.-G., J.-M.T.-T., H.H.-M. (Hassan Hossein-Mohand), and M.-P.C.-R. All authors have read and agreed to the published version of the manuscript.

Funding: This research received no external funding.

Conflicts of Interest: The authors declare no conflict of interest.

\section{References}

1. INE. Estadística de la Sociedad de la Información y la Comunicación en los Centros Educativos no Universitarios. Curso 2018-2019. Available online: https:/www.educacionyfp.gob.es/servicios-al-ciudadano/ estadisticas/no-universitaria/centros/sociedad-informacion/2018-2019.html (accessed on 10 October 2020).

2. Chevallard, Y. La Transposición Didáctica, $2^{a}$ Reimp; Aique Grupo Editor: Buenos Aires, Argentina, 2005.

3. Vergnaud, G. Why the theory of conceptual fields? Infanc. Aprendiz. 2013, 36, 131-161. [CrossRef]

4. Trouche, L.; Monaghan, J.; Borwein, J.M. Didactics of Mathematics: Concepts, Roots, Interactions and Dynamics from France; Springer: Cham, Switzerland, 2016; Volume 110, pp. 219-256.

5. Butlen, D.; Masselot, P. Challenges and modalities of formation for the teachers of the schools in didactics of mathematics. Can. J. Sci. Math. Technol. Educ. 2019, 19, 91-106. [CrossRef] 
6. Lagrange, J.-B.; Artigue, M.; Laborde, C.; Trouche, L. Technology and mathematics education: A multidimensional study of the evolution of research and innovation. In Second International Handbook of Mathematics Education; Springer: Amsterdam, The Netherlands, 2003; pp. 237-269.

7. Kieran, C.; Drijvers, P. Digital technology and mathematics education: Core ideas and key dimensions of Michèle Artigue's theoretical work on digital tools and its impact on mathematics education research. In The Didactics of Mathematics: Approaches and Issues; Springer: Amsterdam, The Netherlands, 2016; pp. 123-142.

8. Trouche, L.; Rocha, K.; Gueudet, G.; Pepin, B. Transition to digital resources as a critical process in teachers' trajectories: The case of Anna's documentation work. ZDM Math. Educ. 2020. [CrossRef]

9. Olive, J.; Makar, K.; Hoyos, V.; Kor, L.K.; Kosheleva, O.; Straesser, R. Mathematical Knowledge and Practices Resulting from access to Digital Technologies. In Mathematics Education and Technology-Rethinking the Terrain, 17th ICMI Study; Springer: Boston, MA, USA, 2010; Volume 13, pp. 133-177. [CrossRef]

10. Moreno, M.; Llinares, S. Prospective Mathematics Teachers' Perspectives on Technology. In Educating Prospective Secondary Mathematics Teachers: Knowledge, Identity and Pedagogical Practices; Strutchens, M.E., Huang, R., Potari, D., Losano, L., Eds.; Springer: Berlin/Heidelberg, Germany, 2018; pp. 125-142.

11. Hollebrands, K.; Okumus, S. Secondary mathematics teachers' instrumental integration in technology-rich geometry classrooms. J. Math. Behav. 2018, 49, 82-94. [CrossRef]

12. Healy, L.; Lagrange, J.-B. Introduction to section 3. In Mathematics Education and Technology-Rethinking the Terrain; Springer: New York, NY, USA, 2009; pp. 287-292.

13. Trouche, L.; Gitirana, V.; Miyakawa, T.; Pepin, B.; Wang, C.Y. Studying mathematics teachers interactions with curriculum materials through different lenses: Towards a deeper understanding of the processes at stake. Int. J. Educ. Res. 2019, 93, 53-67. [CrossRef]

14. Bray, A.; Tangney, B. Technology usage in mathematics education research-A systematic review of recent trends. Comput. Educ. 2017, 114, 255-273. [CrossRef]

15. Forsstrom, S.E. Role of teachers in students' mathematics learning processes based on robotics integration. Learn. Cult. Soc. Interact. 2019, 21, 378-389. [CrossRef]

16. Gui, M.; Parma, A.; Comi, S. Does Public Investment in ICTs Improve Learning Performance? Evidence from Italy. Policy Internet 2018, 10, 141-163. [CrossRef]

17. Guillén-Gámez, F.D.; Mayorga-Fernández, M.J. Identification of Variables that Predict Teachers' Attitudes toward ICT in Higher Education for Teaching and Research: A Study with Regression. Sustainability 2020, 12, 1312. [CrossRef]

18. Mercader, C. Explanatory model of barriers to integration of digital technologies in higher education institutions. Educ. Inf. Technol. 2020. [CrossRef]

19. Liu, Q.; Geertshuis, S.; Grainger, R. Understanding academics' adoption of learning technologies: A systematic review. Comput. Educ. 2020, 151. [CrossRef]

20. Park, J.-H.; Kim, C.; Ham, J. High-school students' understanding and use of mathematics textbooks. Math. Educ. 2019, 58, 589-607.

21. Semerci, A.; Aydin, M.K. Examining High School Teachers' Attitudes towards ICT Use in Education. Int. J. Progress. Educ. 2018, 14, 93-105. [CrossRef]

22. Maio, G.R.; Haddock, G.; Verplanken, B. The Psychology of Attitudes and Attitude Change; Sage Publications Limited: London, UK, 2018.

23. Guillén-Gámez, F.D.; Mayorga-Fernández, M.J.; Bravo-Agapito, J.; Escribano-Ortiz, D. Analysis of Teachers' Pedagogical Digital Competence: Identification of Factors Predicting Their Acquisition. Technol. Knowl. Learn. 2020. [CrossRef]

24. Spiteri, M.; Rundgren, S.-N.C. Literature Review on the Factors Affecting Primary Teachers' Use of Digital Technology. Technol. Knowl. Learn. 2020, 25, 115-128. [CrossRef]

25. Tanas, L.; Winkowska-Nowak, K.; Pobiega, K. The Importance of Teachers' Need for Cognition in Their Use of Technology in Mathematics Instruction. Front. Psychol. 2020, 11, 259. [CrossRef]

26. Hsu, C.-Y.; Tsai, M.-J.; Chang, Y.-H.; Liang, J.-C. Surveying in-service teachers' beliefs about game-based learning and perceptions of technological pedagogical and content knowledge of games. J. Educ. Technol. Soc. 2017, 20, 134-143. 
27. Moreira-Fontan, E.; Garcia-Senoran, M.; Conde-Rodriguez, A.; Gonzalez, A. Teachers' ICT-related self-efficacy, job resources, and positive emotions: Their structural relations with autonomous motivation and work engagement. Comput. Educ. 2019, 134, 63-77. [CrossRef]

28. Sánchez-Prieto, J.C.; Huang, F.; Olmos-Miguelanez, S.; Garcia-Penalvo, F.J.; Teo, T. Exploring the unknown: The effect of resistance to change and attachment on mobile adoption among secondary pre-service teachers. Br. J. Educ. Technol. 2019, 50, 2433-2449. [CrossRef]

29. Skiba, D.J. Horizon Report: Knowledge Obsolescence, Artificial Intelligence, and Rethinking the Educator Role. Nurs. Educ. Perspect. 2017, 38, 165-167. [CrossRef]

30. Varela-Ordorica, S.A.; Valenzuela-González, J.R. Use of Information and Communication Technologies as a Transversal Competence in Teacher Training. Rev. Electrónica Educ. 2020, 24, 172-191. [CrossRef]

31. Dostal, J.; Wang, X.; Nuangchalerm, P. Experiments in Education Supported by Computer Use: Teachers' Attitudes towards Computers. In Proceedings of the 9th International Conference on Computer Supported Education (Csedu), Porto, Portugal, 21-23 April 2017; Volume 2, pp. 248-254. [CrossRef]

32. Bond, M. Facilitating student engagement through the flipped learning approach in K-12: A systematic review. Comput. Educ. 2020, 151. [CrossRef]

33. Hinojo Lucena, F.J.; López Belmonte, J.; Fuentes Cabrera, A.; Trujillo Torres, J.M.; Pozo Sánchez, S. Academic effects of the use of flipped learning in physical education. Int. J. Environ. Res. Public Health 2020, 17, 276. [CrossRef] [PubMed]

34. Lo, C.K.; Lie, C.W.; Hew, K.F. Applying "First Principles of Instruction" as a design theory of the flipped classroom: Findings from a collective study of four secondary school subjects. Comput. Educ. 2018, 118, 150-165. [CrossRef]

35. Beserra, V.; Nussbaum, M.; Oteo, M. On-Task and Off-Task Behavior in the Classroom: A Study on Mathematics Learning With Educational Video Games. J. Educ. Comput. Res. 2019, 56, 1361-1383. [CrossRef]

36. Deng, L.; Wu, S.; Chen, Y.; Peng, Z. Digital game-based learning in a Shanghai primary-school mathematics class: A case study. J. Comput. Assist. Learn. 2020. [CrossRef]

37. Vanbecelaere, S.; Van den Berghe, K.; Cornillie, F.; Sasanguie, D.; Reynvoet, B.; Depaepe, F. The effects of two digital educational games on cognitive and non-cognitive math and reading outcomes. Comput. Educ. 2020, 143. [CrossRef]

38. Dalby, D. Professional learning through collaborative research in mathematics. Prof. Dev. Educ. $2019,15$. [CrossRef]

39. Mora, H.; Teresa Signes-Pont, M.; Fuster-Guillo, A.; Pertegal-Felices, M.L. A collaborative working model for enhancing the learning process of science \& engineering students. Comput. Hum. Behav. 2020, 103, 140-150. [CrossRef]

40. Kim, H.-K. Meta analysis on the improvement of academic performance by the teaching method for underachievers of learning mathematics. Math. Educ. 2020, 59, 31-45.

41. Panahi, M.; Jafarkhani, F.; Bozorg, Z.J.; Nikkho, L. Reviewing learning environments: Effect of flipped classroom on learning levels of mathematics in primary schools. In Proceedings of the 12th annual International Conference of Education, Research and Innovation, Seville, Spain, 11-13 November 2019; Chova, L.G., Martinez, A.L., Torres, I.C., Eds.; 2019; pp. 8561-8566.

42. Dalby, D.; Swan, M. Using digital technology to enhance formative assessment in mathematics classrooms. Br. J. Educ. Technol. 2019, 50, 832-845. [CrossRef]

43. Fernández-Batanero, J.M.; Cabero, J. Knowledge and degree of training of primary education teachers in relation to ICT taught to disabled students. Br. J. Educ. Technol. 2019, 50. [CrossRef]

44. Andersen, S.C.; Beuchert, L.; Nielsen, H.S.; Thomsen, M.K. The effect of teacher's aides in the classroom: Evidence from a randomized trial. J. Eur. Econ. Assoc. 2020, 18, 469-505. [CrossRef]

45. Mikropoulos, T.A. Research on E-Learning and ICT in Education: Technological, Pedagogical and Instructional Perspectives; Springer: Cham, Switzerland, 2018.

46. Alemayehu, G.; Natarajan, M. Impact of ICT facility on student's academic performance in Jimma University, Ethiopia. Int. J. Inf. Dissem. Technol. 2018, 8, 136-142. [CrossRef]

47. Fernandes, G.W.R.; Rodrigues, A.M.; Ferreira, C.A. Professional development and use of digital technologies by science teachers: A review of theoretical frameworks. Res. Sci. Educ. 2018, 50, 673-708. [CrossRef]

48. Chen, I.H.; Gamble, J.H.; Lee, Z.-H.; Fu, Q.-L. Formative assessment with interactive whiteboards: A one-year longitudinal study of primary students' mathematical performance. Comput. Educ. 2020, 150. [CrossRef] 
49. Brecka, P.; Valentova, M.; Haskova, A. Development of students' key competences and knowledge through interactive whiteboard. Ad Alta J. Interdiscip. Res. 2019, 9, 19-28.

50. Aflalo, E.; Zana, L.; Huri, T. The interactive whiteboard in primary school science and interaction. Interact. Learn. Environ. 2018, 26, 525-538. [CrossRef]

51. Burke, P.F.; Schuck, S.; Aubusson, P.; Kearney, M.; Frischknecht, B. Exploring teacher pedagogy, stages of concern and accessibility as determinants of technology adoption. Technol. Pedagog. Educ. 2018, 27, 149-163. [CrossRef]

52. OECD. Panorama de la Educación 2015. Available online: https://www.oecd-ilibrary.org/panorama-dela-educacion-2015-indicadores-de-la-ocde_5jlz4xc81njc.pdf?itemId=\%2Fcontent $\% 2$ Fpublication $\% 2$ Feag2015-es\&mimeType $=$ pdf (accessed on 10 October 2020).

53. Kundu, A.; Bej, T.; Dey, K.N. An empirical study on the correlation between teacher efficacy and ICT infrastructure. Int. J. Inf. Learn. Technol. 2020. [CrossRef]

54. De Brabander, C.J.; Glastra, F.J. The unified model of task-specific motivation and teachers' motivation to learn about teaching and learning supportive modes of ICT use. Educ. Inf. Technol. 2020. [CrossRef]

55. Califf, C.B.; Brooks, S. An empirical study of techno-stressors, literacy facilitation, burnout, and turnover intention as experienced by K-12 teachers. Comput. Educ. 2020, 157. [CrossRef]

56. Li, L.; Wang, X. Technostress inhibitors and creators and their impacts on university teachers' work performance in higher education. Cogn. Technol. Work 2020. [CrossRef]

57. Zee, M.; Koomen, H.M.Y. Teacher Self-Efficacy and Its Effects on Classroom Processes, Student Academic Adjustment, and Teacher Well-Being: A Synthesis of 40 Years of Research. Rev. Educ. Res. 2016, 86, 981-1015. [CrossRef]

58. Wang, X.H.; Tan, S.C.; Li, L. Measuring university students' technostress in technology-enhanced learning: Scale development and validation. Australas. J. Educ. Technol. 2020, 36, 96-112. [CrossRef]

59. Comi, S.L.; Argentin, G.; Gui, M.; Origo, F.; Pagani, L. Is it the way they use it? Teachers, ICT and student achievement. Econ. Educ. Rev. 2017, 56, 24-39. [CrossRef]

60. García, M.G.; Hamed, M.B.; Dorado, C.P.; Valera, R.S. Formación docente en línea a distancia. Un análisis de los perfiles y la opinión de los profesores. Rev. Electrón. Interuniv. Form. Profr. 2020, 23. [CrossRef]

61. Napal Fraile, M.; Penalva-Velez, A.; Mendioroz Lacambra, A.M. Development of Digital Competence in Secondary Education Teachers' Training. Educ. Sci. 2018, 8, 104. [CrossRef]

62. Hinojo-Lucena, F.-J.; Aznar-Díaz, I.; Cáceres-Reche, M.-P.; Trujillo-Torres, J.-M.; Romero-Rodríguez, J.-M. Factors influencing the development of digital competence in teachers: Analysis of the teaching staff of permanent education centres. IEEE Access 2019, 7, 178744-178752. [CrossRef]

63. Cekse, I.; Geske, A.; Pole, O. Teacher in Citizenship Education Learning Process. In Society, Integration, Education, Volume II, 2018: School Pedagogy, Preschool Pedagogy; Rezekne Academy of Technologies: Rezekne, Latvia, 2018; pp. 84-92. [CrossRef]

64. Gebhardt, E.; Thomson, S.; Ainley, J.; Hillman, K. Teacher Gender and ICT. In Gender Differences in Computer and Information Literacy; Springer: Cham, Switzerland, 2019; pp. 53-68.

65. Cussó-Calabuig, R.; Farran, X.C.; Bosch-Capblanch, X. Effects of intensive use of computers in secondary school on gender differences in attitudes towards ICT: A systematic review. Educ. Inf. Technol. 2018, 23, 2111-2139. [CrossRef]

66. Sánchez-Prieto, J.; Trujillo-Torres, J.M.; Gómez-García, M.; Gómez-García, G. Gender and Digital Teaching Competence in Dual Vocational Education and Training. Educ. Sci. 2020, 10, 84. [CrossRef]

67. Prendes-Espinosa, M.-P.; Garcia-Tudela, P.-A.; Solano-Fernandez, I.-M. Gender equality and ICT in the context of formal education: A systematic review. Comunicar 2020, 28, 9-20. [CrossRef]

68. Informe 2019 Sobre el Estado del Sistema Educativo: Curso 2017-2018. Available online: http: //www.educacionyfp.gob.es/dam/jcr:4f35ae94-f996-4ceb-b3f0-21b2e421ec26/i19cee-informe.pdf (accessed on 10 October 2020).

69. Vallés Martínez, M.S.; d’ancona, C.; Angeles, M.; Izquierdo Escribano, A. Las Encuestas Sobre Inmigración en España y en Europa. Tópicos, Medios de Comunicación y Política Migratoria. In Informe Sobre els Gitanos Romanesos a Barcelona; Ministerio de Trabajo y Asuntos Sociales, Observatorio Permanente de la Inmigración: Madrid, Spain, 1999.

70. Rosenbluth, A.; Cruzat-Mandich, C.; Ugarte, M.L. Methodology to Validate a Competencies Assessment Tool for Psychology Students. Univ. Psychol. 2016, 15, 303-314. 
71. Yee, T.W. Quantile regression via vector generalized additive models. Stat. Med. 2004, 23, $2295-2315$. [CrossRef]

72. Yeo, I.K.; Johnson, R.A. A new family of power transformations to improve normality or symmetry. Biometrika 2000, 87, 954-959. [CrossRef]

73. INE. Encuesta Sobre Equipamiento y uso de Tecnologías de Información y Comunicación en los Hogares. Available online: https://www.ine.es/CDINEbase/consultar.do?mes=Octubre+2019\&id_mes=Ir\&operacion= $\& \mathrm{~L}=0$ (accessed on 10 October 2020).

74. Aktas, F.N.; Argun, Z. Examination of Mathematical Values in Classroom Practices: A Case Study of Secondary Mathematics Teachers. Egit. Bilim Educ. Sci. 2018, 43, 121-141. [CrossRef]

75. Arnal-Bailera, A.; Cid, E.; Muñoz-Escolano, J.M.; Oller-Marcén, A.M. Marking Mathematics Exams. A Tool for Secondary Teacher Education. In Educating Prospective Secondary Mathematics Teachers; Springer: Cham, Switzerland, 2018; pp. 245-265.

76. Martin, D.; Jamieson-Proctor, R. Development and validation of a survey instrument for measuring pre-service teachers' pedagogical content knowledge. Int. J. Res. Method Educ. 2019. [CrossRef]

77. Santagata, R.; Sandholtz, J.H. Preservice Teachers' Mathematics Teaching Competence: Comparing Performance on Two Measures. J. Teach. Educ. 2019, 70, 472-484. [CrossRef]

78. Griffith, S.F.; Hagan, M.B.; Heymann, P.; Heflin, B.H.; Bagner, D.M. Apps As Learning Tools: A Systematic Review. Pediatrics 2020, 145. [CrossRef]

79. Wang, X.H.; Li, B. Technostress among University Teachers in Higher Education: A Study Using Multidimensional Person-Environment Misfit Theory. Front. Psychol. 2019, 10, 1791. [CrossRef]

80. Tondeur, J.; Scherer, R.; Baran, E.; Siddiq, F.; Valtonen, T.; Sointu, E. Teacher educators as gatekeepers: Preparing the next generation of teachers for technology integration in education. Br. J. Educ. Technol. 2019, 50, 1189-1209. [CrossRef]

Publisher's Note: MDPI stays neutral with regard to jurisdictional claims in published maps and institutional affiliations.

(C) 2020 by the authors. Licensee MDPI, Basel, Switzerland. This article is an open access article distributed under the terms and conditions of the Creative Commons Attribution (CC BY) license (http://creativecommons.org/licenses/by/4.0/). 